\title{
Inhaled Corticosteroid Treatment in Chronic Obstructive Pulmonary Disease (COPD): Boon or Bane?
}

\author{
Alan G. Kaplan, MD
}

\begin{abstract}
Inhaled corticosteroid (ICS)-based therapy is often used for patients with chronic obstructive pulmonary disease (COPD). However, this approach is under scrutiny because of ICS overuse in patients for whom it is not recommended and because of concerns about adverse events, particularly pneumonia, with long-term ICS use. Evidence suggests ICS may be beneficial in specific patients, namely, those with high blood eosinophil counts $(\mathrm{eg}, \geq 300 \mathrm{cells} / \mu \mathrm{L})$ or who are at a high risk of exacerbations. According to the Global Initiative for Chronic Obstructive Lung Disease (GOLD) 2020 ABCD assessment tool, these patients belong in group D. For these patients, recommended initial treatment includes ICS in combination with long-acting $\beta 2$-agonists (LABAs) when blood eosinophil counts are $\geq 300$ cells $/ \mu \mathrm{L}$ or LABA + long-acting muscarinic antagonist (LAMA) when patients are highly symptomatic, that is, with greater dyspnea and/or exercise limitation. Follow-up treatments for patients with persistent dyspnea and/or exacerbations may include LABA + ICS, LABA + LAMA, or LABA + LAMA + ICS, with use of ICS being guided by blood eosinophil counts. In this review, differences in the inflammatory mechanism underlying COPD and asthma and the role of ICS treatment in COPD are summarized. Furthermore, findings from recent clinical trials where use of ICS-based dual or triple therapy in COPD was compared with LABA + LAMA therapy and trials in which ICS withdrawal was evaluated in patients with COPD are reviewed. Finally, a step-by-step guide for ICS withdrawal in patients who are unlikely to benefit from this treatment is proposed. A video of the author discussing the overall takeaway of the review article could be downloaded from the link provided: https://www.youtube.com/watch?v=Uq7Sr5jqPDI. ( $\mathrm{J}$ Am Board Fam Med 2020;33:289-302.)
\end{abstract}

Keywords: Chronic Obstructive Pulmonary Disease, Inhaled Corticosteroids, Global Initiative for Chronic Obstructive Lung Disease (GOLD), Eosinophil

\section{Introduction}

Inhaled corticosteroids (ICS), which are antiinflammatory agents whose effects are mediated by activation of glucocorticoid receptors, are the cornerstone of asthma treatment. ${ }^{1,2}$ However, their use in

This article was externally peer reviewed.

Submitted 26 June 2019; revised 11 October 2019; accepted 14 October 2019.

From the Family Physician Airways Group of Canada, University of Toronto, Toronto, ON, Canada (AGK)

Funding: The research was funded by Boehringer Ingelheim Pharmaceuticals, Inc.

Conflict of interest: AK serves on the advisory board and speakers' bureau for Boehringer Ingelheim, AstraZeneca, Purdue, Teva, Trudel, and Novartis; serves on the advisory board for GlaxoSmithKline, Mylan, Paladin, and Novo Nordisk; is a speaker for Grifols and Merck Frosst; and an advisor on Johnson and Johnson's smoking cessation website design, outside of the submitted work.

Corresponding author: Alan G. Kaplan, MD, Family Physician Airways Group of Canada, 7335 Yonge Street, chronic obstructive pulmonary disease (COPD) is controversial. $^{2-4}$ Although asthma and COPD share similar pathophysiologic features, such as chronic inflammation of the respiratory tract and airflow limitation, they differ markedly in the pattern of inflammation. ${ }^{5}$ Different inflammatory cells are recruited to bronchial airways, and various inflammatory mediators are subsequently released..$^{5}$ For example, in asthma, the cells that infiltrate the airway surface include eosinophils, activated mucosal mast cells, and T cells, whereas in COPD, infiltrates mostly comprise neutrophils and $\mathrm{T}$ cells. ${ }^{5}$ Furthermore, in patients with asthma, ICS suppress inflammation by switching off activated inflammatory genes with the help of nuclear enzyme histone deacetylase 2, which are poorly

Thornhill, Ontario Canada, L3T 2B2 (E-mail: for4kids@ gmail.com). 
expressed in inflammatory cells and peripheral lungs in patients with COPD. ${ }^{5}$

Despite immunologic differences in disease etiology, ICS are overused in patients with COPD. ${ }^{6-9}$ This sparks interest because they are not indicated in most patients ${ }^{10}$ and can increase the risk of a number of adverse events including pneumonia. ${ }^{11}$ Therefore, identifying the right patients with COPD who will benefit from ICS treatment is important. ICS are only recommended in specific patients with COPD and can be used with effect in combination with single or dual bronchodilators (long-acting $\beta_{2}$-agonists [LABAs] and long-acting muscarinic antagonists [LAMAs]). ${ }^{10}$ Bronchodilators reduce airflow obstruction and air trapping by causing bronchodilation and reducing hyperinflation, respectively. ${ }^{12}$ While ICS monotherapy in COPD does not improve lung function or reduce mortality rates, ${ }^{13}$ when combined with a LABA, reductions in exacerbations and moderate improvements in lung function and health status have been observed. ${ }^{14}$ In this review, the benefits and risks of ICS treatment in patients with COPD are discussed.

\section{Global Initiative for Chronic Obstructive Lung Disease Patient Classification}

The Global Initiative for Chronic Obstructive Lung Disease (GOLD) outlines a strategy for the management of COPD, which is updated regularly based on recently published scientific literature. ${ }^{10}$ In the 2017 update, the "ABCD" assessment tool was revised to offer improved individualized treatment to patients. ${ }^{10}$ Since the 2019 update, the ABCD tool is used only to guide initial treatment, while follow-up treatment is based on the most treatable trait and current treatment. Using the tool, patients are classified into groups A to D based on symptom severity (measured by the COPD Assessment Test [CAT] or the modified British Medical Research Council questionnaire [mMRC]) and exacerbation history (Figure 1). Patients in group A have fewer symptoms and none or 1 moderate exacerbation, while patients in group $D$ have frequent exacerbations $(\geq 2)$ or $\geq 1$ exacerbation that may lead to hospital admission and report more symptoms. ${ }^{10}$

According to GOLD 2020, recommendations for initial pharmacological therapies are based on individualized assessment of symptoms and exacerbation risk (ABCD group). ${ }^{10}$ However, follow-up treatment recommendations do not depend on the patients' GOLD group determined at diagnosis. ${ }^{10}$ An overview of treatment options is shown in Figure $2 .{ }^{15}$ During initial pharmacological management, shortor long-acting bronchodilators should be offered to all group A patients. ${ }^{10}$ For group B patients, a longacting bronchodilator, either a LABA or a LAMA, is recommended as initial therapy. Use of 2

Figure 1. GOLD ABCD assessment tool. Abbreviations: CAT, COPD Assessment Test; COPD, chronic obstructive pulmonary disease; $\mathrm{FEV}_{1}$, forced expiratory volume in 1 second; FVC, forced viatal capacity; GOLD, Global Initiative for Chronic Obstructive Lung Disease; mMRC, modified British Medical Research Council questionnaire.
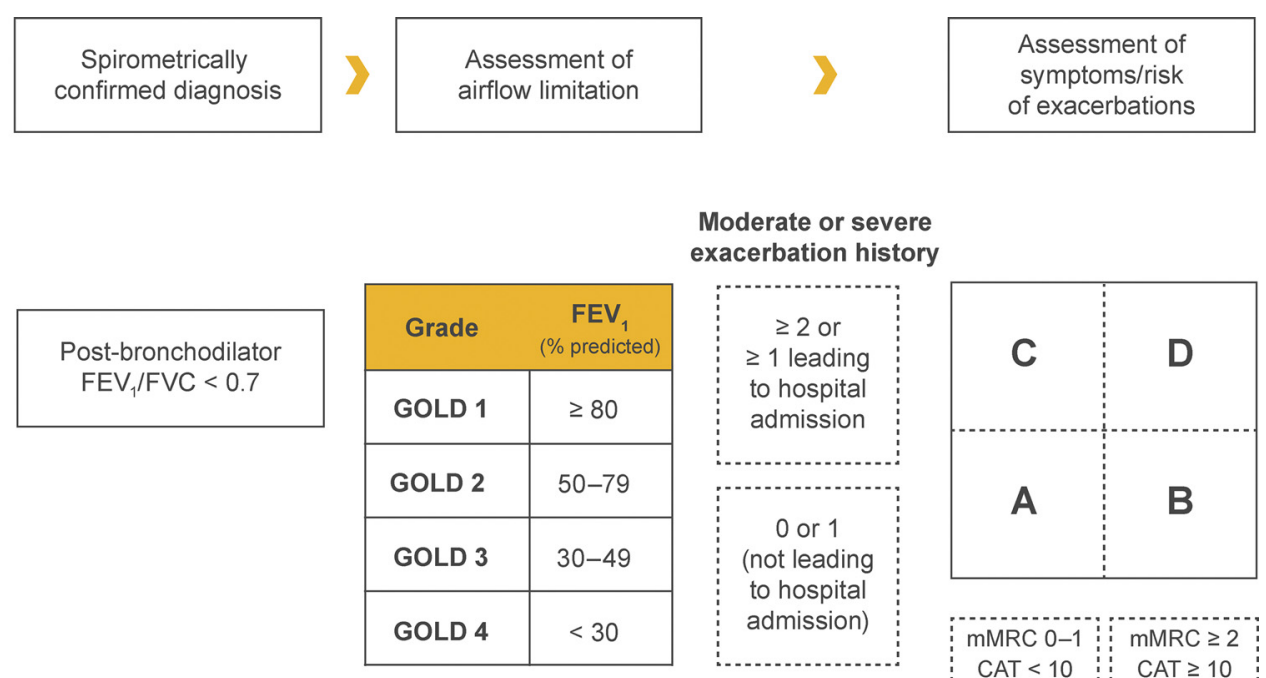
Figure 2. Treatment options for COPD. Abbreviations: COPD, chronic obstructive pulmonary disease; ICS, inhaled corticosteroid; LABA, long-acting $\beta 2$-agonist; LAMA, long-acting antimuscarinic antagonist, PdE4, phosphodiesterase-4; SABD, short-acting bronchodilator.

\section{Non-pharmacologic therapy}

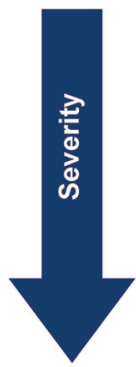

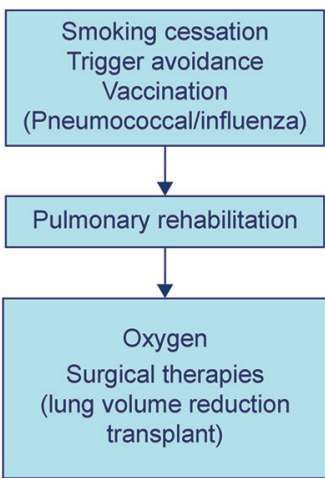

bronchodilators may be considered for group B patients with severe breathlessness or during followup assessment if severe breathlessness persists despite monotherapy. If symptoms do not improve despite therapy with dual bronchodilators, a step-down to monotherapy may be considered. For group C patients, a long-acting bronchodilator, preferably a LAMA, is recommended as initial therapy. If exacerbations persist during follow-up assessment, a LABA + LAMA or LABA + ICS combination is recommended. ${ }^{10}$ For group D patients, initial therapy with LAMA is recommended; if patients have more severe symptoms $(\mathrm{CAT} \geq 20)$ with greater dyspnea and/or exercise limitation, LABA + LAMA is preferable ${ }^{10}$ because dual bronchodilator combination is superior to monotherapy, ${ }^{16}$ and if patients have blood eosinophil counts $\geq 300$ cells $/ \mu \mathrm{L}$ or a history of asthma, LABA + ICS may be considered the first choice. ${ }^{10}$

Some adult patients present with clinical characteristics of both asthma and COPD, commonly referred to as asthma-COPD overlap (ACO). ${ }^{1}$ Patients with ACO have higher disease burden, including frequent hospital stay, shortness of breath, use of oral corticosteroids and oxygen therapy, and emergency department visits, than patients with COPD alone. ${ }^{17}$ For patients with ACO, LAMA or LABA + ICS is recommended. ${ }^{1}$

\section{Inhaled therapy}

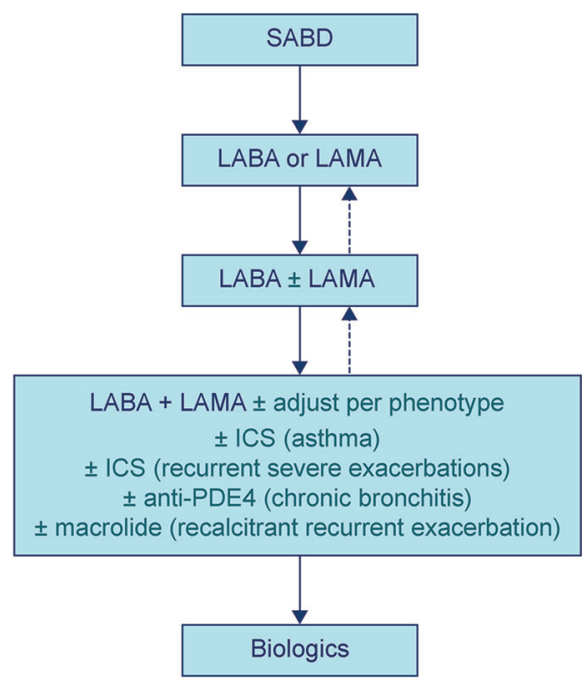

Patients with COPD may have concomitant chronic conditions such as cardiovascular disease, metabolic syndrome, skeletal muscle dysfunction, osteoporosis, anxiety, depression, or lung cancer; therefore, comorbidities should be identified and treated to avoid influence on hospitalization or mortality. ${ }^{10,18}$ Moreover, management of COPD by appropriate nonpharmacologic interventions, such as smoking cessation, nutritional counseling, vaccination, and pulmonary rehabilitation, should also be considered (Figure 2). Although use of ICS is recommended in high-risk patients or GOLD group D, ${ }^{10,19}$ ICS are frequently inappropriately prescribed outside current treatment recommendations for patients with less severe COPD as well, ${ }^{6,8}$ which is both not of value and potentially dangerous due to adverse effects.

\section{Use of ICS in COPD}

Despite a lack of scientific evidence, ICS were prescribed to patients with COPD starting in the early 1980s because of their effectiveness in asthma. ${ }^{20}$ Since then, clinical outcomes with ICS monotherapy and ICS in combination with a bronchodilator have been investigated in numerous trials. ${ }^{13,21,22}$ Results from early trials showed that, while ICS monotherapy reduced moderate exacerbations, 
LABAs were more effective in improving lung function. $^{23}$ These findings prompted trials of ICS + LABA combinations, where reduced exacerbations and improved lung function and health status were observed in patients with COPD. ${ }^{14,24}$ Many of these early trials predated the usage of LAMAs, which did not allow patients to have the opportunity to be treated with LABAs + LAMAs, but have since been shown to be better than LABA + ICS for lung function (ILLUMINATE, LANTERN) ${ }^{25,26}$ and exacerbations (FLAME). ${ }^{27-29}$ In the FLAME trial, patients received a LAMA during a 4-week run-in period, and those who had a COPD exacerbation were withdrawn from the study. ${ }^{29}$ Therefore, while ICS-based therapy may be beneficial in some patients, of concern is the inappropriate overuse of ICS in patients with COPD.

Inappropriate prescribing of ICS has been regularly reported. In a cross-sectional survey of primary and secondary care physicians and their patients in the United States and in 5 European countries in 2011, 39\% of GOLD A and 52\% of GOLD B patients were receiving ICS alone or in combination with a LABA and/or LAMA. ${ }^{30}$ Similarly, in a database study in the UK in $2013,50 \%$ of patients without concomitant asthma in GOLD stage 2 (ie, with moderate airflow limitation) and $49 \%$ of those without exacerbations in the previous year were prescribed ICS-based therapy. ${ }^{7}$ Results from a crosssectional study using 2013 data from the National Ambulatory Medical Care Survey showed that while LABA or ICS was prescribed to $32.3 \%$ of patients, more patients (20.2\%) were prescribed LABA + ICS versus LABA + LAMA (8.8\%). ${ }^{9}$ In another cross-sectional study of $5 \%$ of Medicare beneficiaries, use of LABA + ICS in patients with COPD increased from $41.1 \%$ in 2008 to $49.6 \%$ in $2013 .^{31}$ In a population-based study in the UK, ICS was inappropriately prescribed in almost half of GOLD A/B patients with COPD. ${ }^{6}$ Moreover, in this study, addition of ICS did not provide additional clinical benefit.

Results from several studies have shown that long-term use of ICS alone or in combination with a LABA increased the risk of pneumonia. ${ }^{11,32-34}$ For example, in a 1-year double-blind study, the risk of pneumonia was significantly higher when an ICS was used in combination with a LABA versus LABA alone. ${ }^{32}$ Further, findings from a patientlevel meta-analysis suggested that patients with COPD and lower blood eosinophil counts $(<2 \%)$ who were treated with ICS had more pneumonia events than those with higher counts. ${ }^{35}$ In a nested case-control analysis, discontinuation of ICS was associated with a $37 \%$ decrease in the rate of pneumonia. ${ }^{36}$ However, larger studies are needed to validate this result. In at least 1 study (the SUMMIT trial), however, ICS alone or in combination with a LABA did not increase the risk of pneumonia in patients with moderate COPD. ${ }^{37,38}$ Other adverse events associated with ICS use include the risk of decreased bone density and fractures, ${ }^{39}$ diabetes, ${ }^{40}$ cataracts, ${ }^{41}$ adrenal suppression, ${ }^{42}$ and mycobacterial infections. ${ }^{43}$ Given that long-term ICS use is associated with potentially severe adverse events identifying patients who would benefit is necessary to avoid unnecessary ICS exposure.

\section{Clinical Trial Evidence for LABA + LAMA vs LABA + ICS}

Evidence from numerous clinical studies indicates LABA + LAMA combinations result in better clinical outcomes than LABA + ICS in patients with moderate-to-severe COPD with or without a history of a recent exacerbation (Table 1). ${ }^{25-27,29,43-48}$ In these studies, LABA + LAMA combinations reduced hyperinflation; improved inspiratory capacity, expiratory flow, and bronchodilation; and resulted in fewer exacerbations and a longer time to first exacerbation. Results of a Cochrane review of 11 studies involving 9839 patients with moderate-to-severe COPD without recent exacerbations showed greater improvements in lung function (forced expiratory volume in 1 second $\left[\mathrm{FEV}_{1}\right]$ ) and quality of life $(\mathrm{QoL})$, fewer exacerbations, and a lower risk of pneumonia with LABA + LAMA versus LABA + ICS. ${ }^{49}$ In the Assessment of switching salmeterol/Fluticasone to Indacaterol/Glycopyrronium in A Symptomatic COPD Patient Cohort (FLASH) study, a direct switch from LABA + ICS to LABA + LAMA improved predose $\mathrm{FEV}_{1}$ and forced vital capacity in COPD patients. ${ }^{50}$ Although most studies support the beneficial effects of LABA + LAMA versus LABA + ICS, the latter has shown greater benefit in some instances. For example, in the Informing the Pathway of COPD Treatment (IMPACT) study, which involved 10,355 patients with symptomatic COPD and a history of exacerbation within a year before enrollment, the LABA + ICS combination of vilanterol + fluticasone furoate was superior to the LABA + LAMA combination of vilanterol + 
Table 1. Summary of Clinical Trials Comparing LABA + LAMA with LABA + ICS

\begin{tabular}{|c|c|c|c|c|c|}
\hline Study & $\begin{array}{c}\text { LABA + LAMA vs } \\
\text { LABA + ICS }\end{array}$ & $\begin{array}{l}\text { Number of } \\
\text { Patients } \\
\text { Randomized }\end{array}$ & Duration & Lung Function & Exacerbation \\
\hline $\begin{array}{l}\text { Magnussen et al, } 2012 \\
\text { OCTANE }^{46}\end{array}$ & $\begin{array}{l}\text { Tio }(18 \mu \mathrm{g} \text { once } \\
\text { daily }+ \text { SAL } \\
(50 \mu \mathrm{g} \text { twice daily }) \\
\text { vs SFC (50/500 } \mu \mathrm{g} \\
\text { twice daily) }\end{array}$ & 344 & 8 weeks & $\begin{array}{l}\text { Relative to SFC, Tio + } \\
\text { SAL: } \\
\text {-lowered postdose } \\
\text { thoracic gas volume by } \\
182 \pm 44 \mathrm{~mL} \text { after } \\
4 \text { weeks }(P<.0001) \text { and } \\
87 \pm 44 \mathrm{~mL} \text { after } 8 \text { weeks } \\
(P<.05) \text {-nonsignificantly } \\
\text { increased exercise } \\
\text { endurance time }(20 \pm 15 \\
\text { seconds at } 4 \text { weeks, } \\
15 \pm 13 \text { seconds at } \\
8 \text { weeks) }\end{array}$ & $\begin{array}{l}\text { Tio + SAL vs SFC } \\
29(8.4 \%) \text { vs } 24 \\
(7.3 \%)\end{array}$ \\
\hline $\begin{array}{l}\text { Vogelmeier et al, } 2013 \\
\text { ILLUMINATE }^{25}\end{array}$ & $\begin{array}{l}\text { IND + GLY (110/ } \\
50 \mu \mathrm{g} \text { once daily) } \\
\text { vs SFC (50/500 } \mu \mathrm{g} \\
\text { twice daily) }\end{array}$ & 522 & 26 weeks & $\begin{array}{l}\text { IND + GLY vs SFC: } \\
\text {-FEV } 1 \text { AUC } 0 \text { to } 12 \text { hours } \\
\text { was significantly higher } \\
\text { (treatment difference } \\
138 \mathrm{~mL} ; 95 \% \text { CI: } 100 \text { to } \\
176 ; P<.0001 \text { ) }\end{array}$ & $\begin{array}{l}\text { COPD worsening } \\
\text { including } \\
\text { exacerbation was } \\
\text { the most } \\
\text { frequent serious } \\
\text { AE: } 0.4 \%(1 / 13) \\
\text { vs } 1.1 \%(3 / 14) \\
\text { for IND + GLY } \\
\text { vs SFC groups, } \\
\text { respectively }\end{array}$ \\
\hline Hoshino et al, $2015^{45}$ & $\begin{array}{l}\text { Tio + IND (18/ } \\
150 \mu \mathrm{g} \text { once daily) } \\
\text { vs SFC (50/250 } \mu \mathrm{g} \\
\text { twice daily) }\end{array}$ & 46 & 16 weeks & $\begin{array}{l}\text { Tio }+ \text { IND vs SFC IC was } \\
\text { significantly higher } \\
(P=.043) \\
\text {-increase in Ai/BSA } \\
(\mathrm{r}=0.535, P=.011) \\
\text {-decrease in WA/BSA } \\
(\mathrm{r}=-0.688, P<.001), \\
\text { WA/Ao }(\mathrm{r}=-0.555, \\
P=.002), \text { and T// } \mathrm{BSA}(\mathrm{r} \\
=-0.542, P=.007)\end{array}$ & Not reported \\
\hline Donohue et al, $2015^{44}$ & $\begin{array}{l}\text { UMEC/VI (62.5/ } \\
25 \mu \mathrm{g} \text { once daily) } \\
\text { vs SFC (50/250 } \mu \mathrm{g} \\
\text { twice daily) }\end{array}$ & 707 & 12 weeks & $\begin{array}{l}\text { UMEC/VI vs SFC } \\
\text {-statistically significant, } \\
\text { clinically meaningful } \\
\text { improvements in } \\
\text { wmFEV }_{1} \text { (study } 1 \text { : } \\
74 \text { mL; } 95 \% \text { CI: } 38 \text { to } \\
\text { 110; study 2: } 101 \mathrm{~mL} \text {; } \\
\text { 95\% CI: } 63 \text { to } 139 \text { ) } \\
\text {-trough FEV } \text { (study } 1 \text { : } \\
82 \text { mL; } 95 \% \text { CI: } 45 \text { to } \\
\text { 119; study } 2: 98 \mathrm{~mL} ; 95 \% \\
\text { CI: } 59 \text { to } 137 \text { ) (all } \\
P<.001 \text { ) }\end{array}$ & $\begin{array}{l}\text { Infrequent } \\
\quad \text { exacerbations }\end{array}$ \\
\hline Singh et al, $2015^{47}$ & $\begin{array}{l}\text { UMEC/VI (62.5/ } \\
25 \mu \mathrm{g} \text { once daily) } \\
\text { vs SFC (50/500 } \mu \mathrm{g} \\
\text { twice daily) }\end{array}$ & 717 & 12 weeks & $\begin{array}{l}\text { UMEC/VI vs SFC } \\
\text {-wmFEV }(80 \mathrm{~mL} ; 95 \% \\
\text { CI: } 46 \text { to } 113) \text {-trough } \\
\text { FEV }(90 \mathrm{~mL} ; 95 \% \mathrm{CI}: \\
55 \text { to } 125)(\text { both } P<.001)\end{array}$ & $\begin{array}{l}\text { UMEC/NI vs SFC } \\
\mathrm{n}=8 \text { vs } 3\end{array}$ \\
\hline $\begin{array}{l}\text { Zhong et al, } 2015 \\
\text { LANTERN }^{26}\end{array}$ & $\begin{array}{l}\text { IND + GLY (110/ } \\
50 \mu \text { g once daily) } \\
\text { vs SFC }(50 / 500 \mu \mathrm{g} \\
\text { twice daily) }\end{array}$ & 744 & 26 weeks & $\begin{array}{l}\text { IND + GLY vs SFC } \\
\text {-superiority for trough } \\
\text { FEV }_{1} \text { (treatment } \\
\text { difference }=75 \mathrm{~mL} ; 95 \% \\
\text { CI: } 44 \text { to } 107 \text { ) -significant } \\
\text { improvement in FEV } \mathrm{FE}_{1} \\
\text { AUC }_{0} \text { to } 4 \text { hours (treatment } \\
\text { difference }=122 \mathrm{~mL} ; 95 \% \\
\text { CI: } 90 \text { to } 154 \text { ) (both } \\
P<.001 \text { ) }\end{array}$ & $\begin{array}{l}\text { IND + GLY vs } \\
\quad \text { SFC n }=53 \text { vs } 81\end{array}$ \\
\hline
\end{tabular}




\begin{tabular}{|c|c|c|c|c|c|}
\hline Study & $\begin{array}{c}\text { LABA + LAMA vs } \\
\text { LABA + ICS }\end{array}$ & $\begin{array}{l}\text { Number of } \\
\text { Patients } \\
\text { Randomized }\end{array}$ & Duration & Lung Function & Exacerbation \\
\hline $\begin{array}{l}\text { Beeh et al, } 2016 \\
\text { ENERGITO }^{43}\end{array}$ & $\begin{array}{l}\text { Tio }+ \text { Olo }(5 / 5 \mu \mathrm{g} \\
\text { and } 2.5 / 5 \mu \mathrm{g} \text { once } \\
\text { daily) vs SFC }(50 / \\
500 \mu \mathrm{g} \text { and } 50 / \\
250 \mu \mathrm{g} \text { twice daily) }\end{array}$ & 229 & 6 weeks & $\begin{array}{l}\text { Tio }+ \text { Olo }(5 / 5 \mu \mathrm{g}) \text { vs SFC } \\
(50 / 500 \mu \mathrm{g}) ; \text { Tio }+ \text { Olo } \\
(5 / 5 \mu \mathrm{g}) \text { vs SFC }(50 / \\
250 \mu \mathrm{g}) ; \text { Tio }+ \text { Olo }(2.5 / \\
5 \mu \mathrm{g}) \text { vs SFC }(50 / 500 \mu \mathrm{g}) ; \\
\text { and Tio + Olo }(2.5 / 5 \mu \mathrm{g}) \\
\text { vs SFC }(50 / 250 \mu \mathrm{g}) \\
\text {-FEV } 1 \text { AUC } 0 \text { to } 12 \\
\text { adjusted mean (S.E.): } \\
129 \mathrm{~mL}(11) ; 125 \mathrm{~mL} \\
(11) ; 106 \mathrm{~mL}(11) ; \\
103 \mathrm{~mL}(11) \text { (all } \\
P<.0001)\end{array}$ & Not reported \\
\hline $\begin{array}{l}\text { Vogelmeier et al, } 2016 \\
\text { AFFIRM }^{48}\end{array}$ & $\begin{array}{l}\text { Aclidinium }+ \\
\text { formoterol ( } 400 / \\
12 \mu \mathrm{g} \text { twice daily) } \\
\text { vs SFC (50/500 } \mu \mathrm{g} \\
\text { twice daily) }\end{array}$ & 933 & 24 weeks & $\begin{array}{l}\text { Aclidinium }+ \text { formoterol vs } \\
\text { SFC-superiority for peak } \\
\mathrm{FEV}_{1} \text { (treatment } \\
\text { difference }=93 \mathrm{~mL} \\
P<.0001)\end{array}$ & $\begin{array}{l}\text { Aclidinium }+ \\
\quad \text { formoterol vs } \\
\text { SFC } n=74 \text { vs } 77 \\
\text { no difference in } \\
\text { incidence }\end{array}$ \\
\hline $\begin{array}{l}\text { Wedzicha et al, } 2016 \\
\text { FLAME }^{29}\end{array}$ & $\begin{array}{l}\text { IND + GLY (110/ } \\
50 \mu \mathrm{g} \text { once daily) } \\
\text { vs SFC (50/500 } \mu \mathrm{g} \\
\text { twice daily) }\end{array}$ & 3362 & 52 weeks & $\begin{array}{l}\text { IND + GLY vs SFC } \\
\text {-significantly improved } \\
\text { trough FEV } \text { Ftreatment } \\
\text { difference }=62 \mathrm{~mL} \\
P<.001)\end{array}$ & $\begin{array}{l}\text { IND + GLY vs } \\
\text { SFC Superiority } \\
\text { for reducing the } \\
\text { annual rate of all } \\
\text { COPD } \\
\text { exacerbations } \\
(3.59 \text { vs } 4.03 ; \mathrm{RR}, \\
0.89 ; 95 \% \mathrm{CI} \text {, } \\
0.83 \text { to } 0.96 ; \\
P=.003)\end{array}$ \\
\hline $\begin{array}{l}\text { Roche et al, } 2017 \\
\text { FLAME }^{27}\end{array}$ & $\begin{array}{l}\text { IND + GLY (110/ } \\
50 \mu \text { once daily) } \\
\text { vs SFC }(50 / 500 \mu \mathrm{g} \\
\text { twice daily) }\end{array}$ & 2048 & 52 weeks & Not reported & $\begin{array}{l}\text { IND + GLY vs } \\
\text { SFC Significant } \\
\text { reduction in } \\
\text { annualized rate } \\
\text { of moderate or } \\
\text { severe } \\
\text { exacerbations } \\
\text { (RR, } 0.80 \\
{[P=.004] \text { and }} \\
0.85[P=.010] \text {, } \\
\text { respectively) and } \\
\text { all exacerbations } \\
\text { (RR, } 0.84 \\
{[P=.004] \text { and }} \\
0.90[P=.030], \\
\text { respectively) }\end{array}$ \\
\hline
\end{tabular}

AE, adverse event; Ai, luminal area; Ao, total area of the airway; AUC, area under the curve; BSA, body surface area; CI, confidence interval; COPD, chronic obstructive pulmonary disease; $\mathrm{FEV}_{1}$, forced expiratory volume in 1 second; GLY, glycopyrronium; ICS, inhaled corticosteroid; IND, indacaterol; IC, inspiratory capacity; LABA, long-acting $\beta 2$-agonist; LAMA, long-acting antimuscarinic antagonist; Olo, olodaterol; RR, rate ratio; SAL, salmeterol; S.E., standard error; SFC, salmeterol + fluticasone; T, absolute wall thickness; Tio, tiotropium; UMEC, umeclidinium; VI, vilanterol; WA, airway wall area; wm, weighted mean.

umeclidinium in reducing the rate of exacerbations. ${ }^{51}$ However, some of these patients had a history of asthma and about two thirds of patients in the LABA + LAMA arm had effectively stepped down therapy (ie, withdrew ICS), which likely lead to COPD exacerbations. ${ }^{51,52}$ In the triple therapy and LABA + ICS arms patients were either maintained or stepped up to an ICS-containing therapy. ${ }^{51,52}$
Results from an open-label crossover study and a retrospective study of the Korean Obstructive Lung Disease (KOLD) cohort in patients with ACO showed that treatment with LABA + ICS improved lung function. ${ }^{53,54}$ Therefore, these results further highlight the importance of identifying the right patients who can benefit from ICS treatment. To identify such patients, a predictive marker for the 
effectiveness of ICS therapy could aid clinical decision-making.

\section{Eosinophils as Markers of Response to ICS}

Exacerbations are periods of acute worsening of respiratory symptoms and account for the largest proportion of COPD burden on the health care system. ${ }^{10}$ Lowering eosinophilic airway inflammation is associated with a reduction in COPD exacerbations. ${ }^{55}$ Moreover, higher blood eosinophil counts are purported to predict increased exacerbation rates and greater treatment effect with LABA + ICS versus LABA alone in patients with COPD. ${ }^{34,56,57}$ For example, in a post-hoc analysis of 2 clinical trials in patients with moderate-to-severe COPD and $\geq 1$ exacerbation within a year before screening, the LABA + ICS combination of vilanterol + fluticasone furoate reduced exacerbations up to $24 \%$ in patients with blood eosinophil counts of $\geq 2$ to $<4 \%, 32 \%$ in those with counts of $4 \%$ to $<6 \%$, and $42 \%$ in those with counts $\geq 6 \%$ compared with vilanterol alone. ${ }^{55}$ These results suggest that an increased blood eosinophil count is likely a predictive marker for response to ICS-based treatment in patients with COPD. However, there are several inconsistencies that should be addressed. First, results from other studies are discordant with these findings and do not show an association between eosinophil counts and treatment response. Results from a French study involving a cohort of smokers and exsmokers showed no difference in symptoms, lung function, exacerbation rate, comorbidities, or treatment in patients with COPD and different eosinophil levels. ${ }^{58}$ In another study involving smokers without COPD (COPD History Assessment In Spain cohort) and patients with COPD (body mass index, degree of airflow obstruction, functional dyspnea, and exercise capacity cohort), blood eosinophil counts were similar in both cohorts and exacerbation rates did not differ in patients with and without eosinophilia. ${ }^{59}$ Second, although blood eosinophils are considered as a biomarker for ICS-based therapy, ${ }^{60}$ they do not represent tissue eosinophilia. ${ }^{61}$ Finally, eosinophil count cutoffs have been a controversial issue. ${ }^{10,62}$ Authors of a recent review reported several barriers to the use of blood eosinophils to predict response to ICS therapy (eg, comorbidities, effort needed to calculate eosinophil counts, diurnal variation in individual blood eosinophil levels, and current medications and treatment) and recommended caution in its use as a biomarker. ${ }^{63}$ Despite these inconsistencies, GOLD 2020 generally recommends blood eosinophil counts $\geq 300$ cells $/ \mu \mathrm{L}$ as a threshold for deciding ICS-based therapy; a threshold of $\geq 100$ cells $/ \mu \mathrm{L}$ can be considered in patients who have experienced $\geq 2$ moderate exacerbations/year or $\geq 1$ severe exacerbation requiring hospitalization in the preceding year. ${ }^{10}$

\section{When Is Escalation to LABA + LAMA + ICS Appropriate?}

Response to dual bronchodilator or LABA + ICS treatment could guide escalation to triple therapy. According to the GOLD 2020 report, escalation to triple therapy with a LABA + LAMA + ICS is recommended for patients who develop exacerbations despite maximized LABA + LAMA treatment or if patients have persistent breathlessness or exercise limitation despite LABA + ICS..$^{10}$ Addition of roflumilast or a macrolide or stopping ICS is recommended if exacerbations persist despite triple therapy. ${ }^{10}$ The efficacy of triple therapy delivered by 2 inhalers or a single inhaler has been reported in several studies; ${ }^{51,64-68}$ however, single-inhaler therapy is generally preferable to avoid inhalation errors and improve adherence. ${ }^{69}$ Table 2 summarizes clinical trial evidence for ICS-based therapy in patients with COPD. In 2 clinical trials, fluticasone + umeclidinium + vilanterol significantly improved lung function and QoL compared with placebo + fluticasone + vilanterol in patients with COPD. ${ }^{66}$ In the GLISTEN study, glycopyrronium + fluticasone + salmeterol delivered using 2 inhalers improved lung function and QoL, and reduced the use of rescue medication in patients with moderate-to-severe COPD over 12 weeks compared with placebo + fluticasone + salmeterol. ${ }^{64}$ In the long-term (52-week) TRILOGY study, single-inhaler, fixed-dose beclomethasone + formoterol + glycopyrronium improved lung function and reduced exacerbations compared with beclomethasone + formoterol. ${ }^{67}$ In the TRINITY study, this fixed-dose triple therapy reduced exacerbation rates compared with tiotropium alone and had similar effects as open triple therapy of beclomethasone + formoterol plus tiotropium. ${ }^{70}$

The Lung Function and Quality of Life Assessment in COPD with Closed Triple Therapy (FULFIL) study was designed to resemble real-life clinical practice by allowing patients to continue on their prestudy medication up to randomization and including patients with common comorbidities who are often excluded from other studies. ${ }^{65}$ Results of this 
Table 2. Current Clinical Trial Evidence for ICS-Based Therapy in Patients with COPD

\begin{tabular}{|c|c|}
\hline $\begin{array}{l}\text { Characteristics of Patients } \\
\text { with COPD }\end{array}$ & References \\
\hline $\begin{array}{l}\text { Patients with coexistent } \\
\text { asthma or asthma } \\
\text { history }\end{array}$ & $\begin{array}{l}\text { Lim et al, 2014 } \\
\text { Pascoe et al, 2015 } \\
\text { Ishiura et al, } 2015^{53} \\
\text { Lee et al, } 2016 \text { (KOLD) })^{54} \\
\text { Lipson et al, } 2018 \text { (IMPACT) })^{51}\end{array}$ \\
\hline $\begin{array}{l}\text { Patients with } \\
\text { eosinophils }<600 \\
\text { cells } / \mu \mathrm{L}\end{array}$ & $\begin{array}{l}\text { Roche et al, } 2017 \text { (FLAME) }^{27} \\
\text { Chapman et al, } 2018 \text { (SUNSET) })^{85}\end{array}$ \\
\hline $\begin{array}{l}\text { Patients on LABA/ } \\
\text { LAMA who continue } \\
\text { to exacerbate }\end{array}$ & $\begin{array}{l}\text { Singh et al, } 2016 \text { (TRILOGY) }^{67} \\
\text { Vestbo et al, } 2017 \text { (TRINITY) }^{70} \\
\text { Lipson et al, } 2017 \text { (FULFIL) }{ }^{65} \\
\text { Papi et al, } 2018 \text { (TRIBUTE) }{ }^{71} \\
\text { Halpin et al, } 2018 \text { (FULFIL) } \text { (F6 }^{86}\end{array}$ \\
\hline $\begin{array}{l}\text { Patients with } \\
\text { eosinophils } \geq 300 \\
\text { cells } / \mu \mathrm{L} \text { and a history } \\
\text { of } \geq 1 \text { exacerbation in } \\
\text { previous year }\end{array}$ & $\begin{array}{l}\text { Watz et al, } 2016 \text { (WISDOM) } \\
\text { Wedzicha et al, } 2016 \text { (FLAME) }^{29} \\
\text { Calverley et al, } 2017 \text { (WISDOM) } \\
\text { Papi et al, } 2018 \text { (FLAME) } \\
\text { Chapman et al, } 2018 \text { (SUNSET) } \\
\text { Anzueto et al, } 2018 \text { (FLAME) } \\
\text { As }\end{array}$ \\
\hline $\begin{array}{l}\text { Patients with severe } \\
\text { COPD and } \\
\text { recalcitrant sympton }\end{array}$ & Bourbeau et al, $2017^{19}$ \\
\hline
\end{tabular}

COPD, chronic obstructive pulmonary disease; ICS, inhaled corticosteroid; LABA, long-acting $\beta 2$-agonist; LAMA, longacting antimuscarinic antagonist.

study showed that single-inhaler fluticasone + umeclidinium + vilanterol significantly improved lung function and patient-reported outcomes, and reduced the rate of moderate or severe exacerbations, compared with budesonide + formoterol in patients with advanced, symptomatic COPD who were at risk of exacerbations. $^{65}$ Results of the IMPACT study showed that single-inhaler fluticasone + umeclidinium + vilanterol significantly reduced the annual rate of moderate or severe exacerbations compared with fluticasone + vilanterol (by $15 \%$ ) or umeclidinium + vilanterol (by $25 \%$ ) in patients with symptomatic COPD (Figure 3). ${ }^{51}$ The risk of pneumonia was significantly higher with triple therapy versus umeclidinium + vilanterol. Approximately $20 \%$ of patients in IMPACT had bronchodilator reversibility, and therefore met the criteria for asthma and needed an ICS. Thus, these patients were likely vulnerable to exacerbation on withdrawal of ICS. In addition, almost $40 \%$ of the patients were receiving triple therapy at baseline and patients with a history of asthma were included, which may have affected results. ${ }^{52}$ In the
TRIBUTE study, single-inhaler beclomethasone + formoterol + glycopyrronium significantly reduced the rate of moderate-to-severe exacerbations compared with indacaterol + glycopyrronium in patients with symptomatic COPD and an exacerbation history despite maintenance therapy (Figure 3). The occurrence of pneumonia was similar in the 2 groups. ${ }^{71} \mathrm{In}$ the KRONOS study, single-inhaler budesonide + glycopyrrolate + formoterol fumarate improved lung function versus budesonide + formoterol fumarate in patients with mild-to-very-severe COPD who may not have had a COPD exacerbation the preceding year. ${ }^{72}$ Notably, in the IMPACT, TRIBUTE, and KRONOS studies, approximately two thirds of patients were receiving ICS at baseline $;^{52,71,72}$ in some of these patients, ICS was discontinued and, unsurprisingly, a proportion of these patients experienced exacerbations. These findings reinforce the need to step down carefully. For patients who continue to experience exacerbations despite treatment with triple therapy ${ }^{70}$ treatment with phosphodiesterase-4 inhibitors or macrolides or withdrawal of ICS is recommended. ${ }^{7}$

\section{ICS Withdrawal}

The potential for withdrawing ICS has been evaluated in several studies in an effort to inform future clinical decisions for those patients with COPD who may not truly need ICS-based therapy. In the Indacaterol: Switching Nonexacerbating Patients with Moderate COPD from Salmeterol/Fluticasone to Indacaterol (INSTEAD) Active-Comparator trial ${ }^{73}$ and the RealLife Study on the Appropriateness of Treatment In Moderate COPD Patients (OPTIMO) ${ }^{74}$ at low risk of COPD exacerbations, no differences in lung function, breathlessness, rescue medication use, health status, or COPD exacerbations were observed among patients who switched to a LABA (indacaterol) from an LABA + ICS (salmeterol + fluticasone) combination $^{73}$ or those who withdrew ICS from their LABA + ICS maintenance treatment. ${ }^{74}$ In the Withdrawal of Inhaled Steroids During Optimized Bronchodilator Management (WISDOM) study, patients were stepped up from their existing therapy to triple therapy, before being stepped down. ${ }^{75}$ ICS was withdrawn from patients taking triple therapy in 3 steps over a 12 -week period. ICS withdrawal in high-risk patients taking tiotropium + salmeterol + fluticasone met the prespecified noninferiority criterion with respect to the first moderate or severe COPD exacerbation 
Figure 3. A summary of recent ICS withdrawal studies. Abbreviations: BDP, beclomethasone dipropionate; CI, confidence interval; FF, fluticasone furoate; GLY, glycopyrronium, ICS, inhaled corticosteroid; FEV $_{\mathbf{1}}$, forced expiratory volume in 1 second; IND, indacaterol; LABA, long-acting $\beta 2$-agonist; LAMA, long-acting antimuscarinic antagonist; NA, not applicable; SFC, salmeterol and fluticasone; UMEC, umeclidinium; VI, vilanterol; Tio, tiotropium.

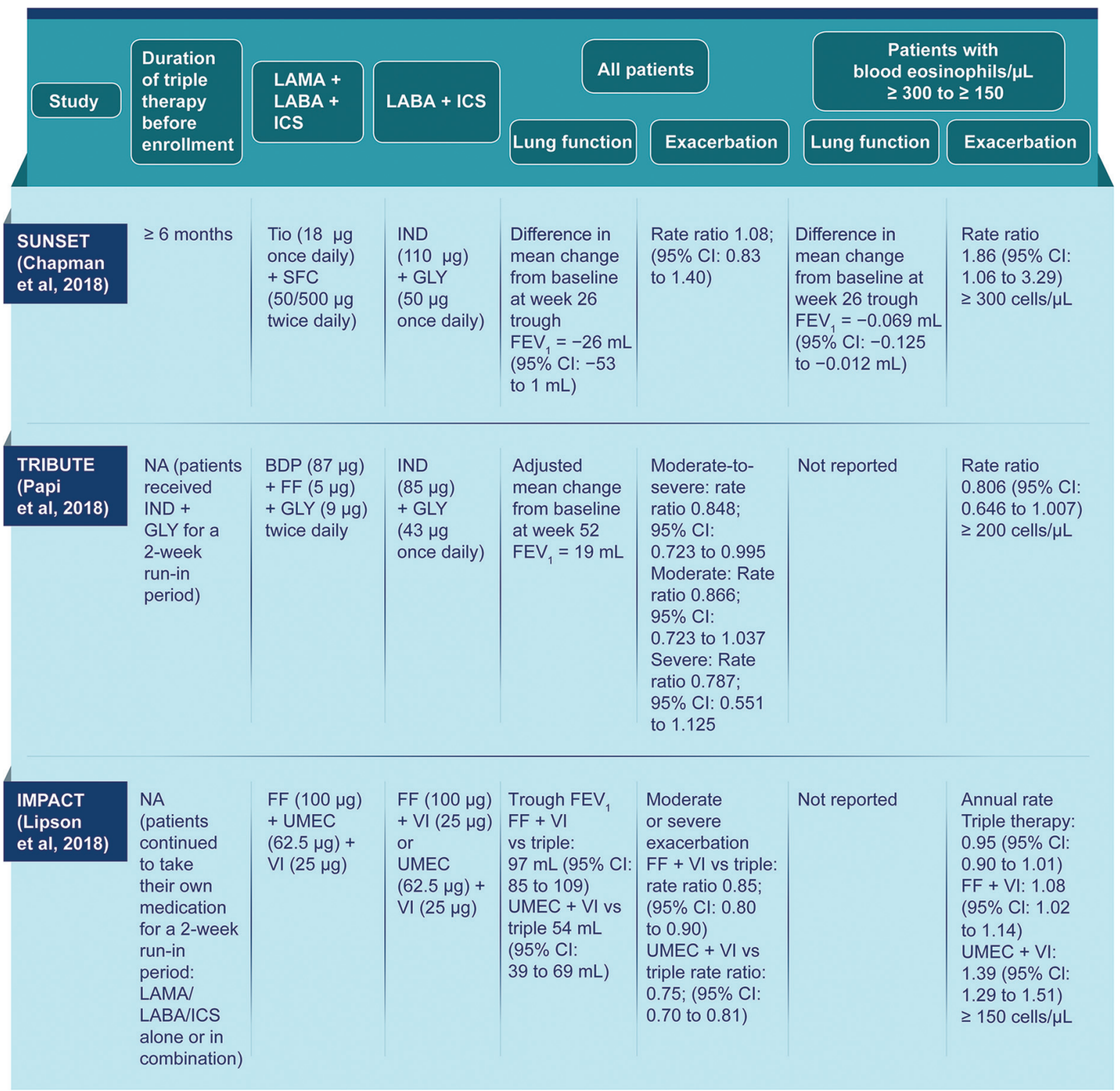

when compared with patients who continued triple therapy. ${ }^{75}$ However, a statistically significant reduction in $\mathrm{FEV}_{1}$ of $43 \mathrm{~mL}$ was reported after ICS withdrawal from low-dose ICS + LABA + LAMA to LABA + LAMA at the last step at week 52.

In 2 post-hoc analyses of WISDOM, ICS withdrawal resulted in higher exacerbation rates in patients with elevated eosinophil counts ( $\geq 300$ cells/ $\mu \mathrm{L})$ and a history of frequent exacerbations ( $\geq 2$ per year). ${ }^{76,77}$ Similarly, in the SUNSET study, withdrawal of ICS in patients on long-term ( $\geq 6$ months) tiotropium + salmeterol + fluticasone with $\leq 1$ exacerbation the previous year resulted in a small decrease in lung function, which was not considered clinically important (Figure 3). ${ }^{78}$ The annualized rate of moderate or severe COPD exacerbations did not differ after ICS withdrawal. Only patients with baseline blood eosinophil counts $\geq 300$ cells $/ \mu \mathrm{L}$ were at an increased risk of exacerbations compared with patients with lower eosinophil counts. While patients with an eosinophil count of $>600$ cells $/ \mu \mathrm{L}$ were excluded in both the FLAME and SUNSET trials, almost no 
Figure 4. A proposed step-by-step approach for ICS withdrawal in patients with COPD. Abbreviations: ACO, asthma-COPD overlap; CAT, COPD Assessment Test; CCQ9, Chronic COPD Questionnaire; COPD, chronic obstrutive pulmonary disease; FeNO, fractional exhaled nitric oxide; GINA, Global Initiative for Asthma; GOLD, Global Initiative for Chronic Obstructive Lung Disease; ICS, inhaled corticosteroid; LABA, long-acting $\beta 2$-agonist; LABD, long-acting bronchodilator; LAMA, long-acting antimuscarinic antagonist; mMRC, modified British Medical Research Council questionnaire; ppb, parts per billion.

Step 1 Review current management of COPD

- Reassess device technique and adherence

- Risk reduction: advice smoking cessation, if necessary, and ensure that immunizations are up-to-date

- Optimize function: encourage physical exercise and ensure adequate nutrition

\section{Step 2 Evaluate the risk-benefit profile of continuing ICS therapy}

- Consider patient history, symptoms (CAT, mMRC, or CCQ9), clinical features, and comorbidities

- Determine spirometry (pre- and post-bronchodilation with LABD held for $\geq 24$ hours)

- If available, consider sputum/blood eosinophil and FeNO levels

\begin{tabular}{|c|c|}
\hline Is it ACO? & Frequent exacerbator? \\
\hline $\begin{array}{l}\text { - History or features of asthma? } \\
\text { - Reversibility (> } 12 \% \text { and } 400 \mathrm{~mL} \text { )? } \\
\text { - Meets the criteria of the } 2014 \\
\text { GINA/GOLD consensus statement? }\end{array}$ & $\begin{array}{l}-\geq 2 \text { moderate-to-severe } \\
\text { exacerbations per year } \\
\cdot \geq 1 \text { hospitalization for } \\
\text { severe exacerbations }\end{array}$ \\
\hline
\end{tabular}

Potential markers (optional):

- Elevated sputum eosinophils (i.e., $\geq 3 \%$ )?

- Elevated blood eosinophils (i.e., $\geq 300 \mathrm{cells} / \mathrm{mm}^{3}$ )?

- Elevated FeNO (i.e., $\geq 25 \mathrm{ppb})$ ?
No

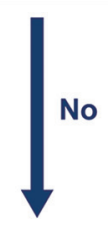

\section{Yes}

Monitor for potential adverse events, particularly

in high-risk patients (e.g., elderly, pneumonia,

tuberculosis, diabetes, osteoporosis, glaucoma/cataracts)

\section{Step 3}

Stepwise withdrawal of ICS

- Initiate stepwise withdrawal of ICS depending on the patient's current ICS dose

\section{What is the current ICS dose?}
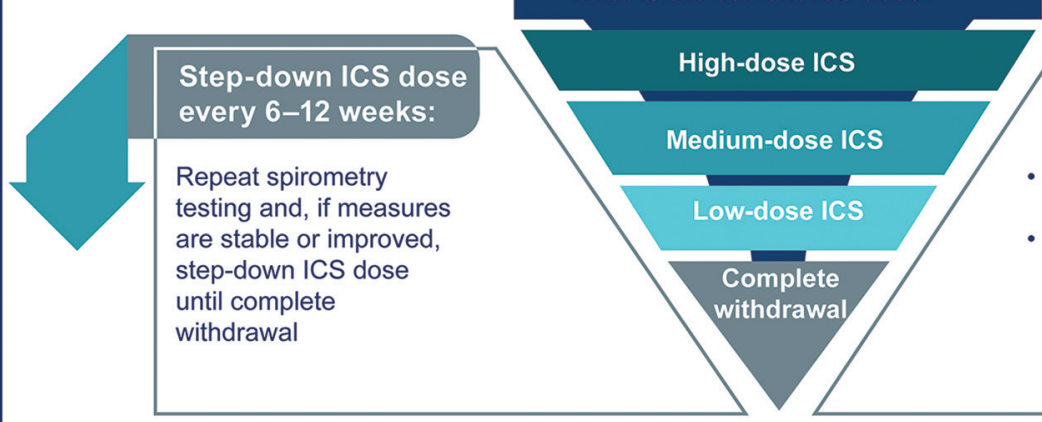

\section{Step-up ICS dose if:}

- Any moderate or severe exacerbations

- Elevated eosinophil (sputum: $\geq 3 \%$; blood: $\geq 300$ cells $\left./ \mathrm{mm}^{3}\right)$ or FeNO ( $\geq 25 \mathrm{ppb})$ levels, if available

\section{At each step:}

- Consider optimizing bronchodilation with LABA + LAMA if the patient is symptomatic (see Step 4)

- Exercise caution in patients with risk factors for repeat exacerbations (e.g., comorbidities/extrapulmonary manifestations, chronic bronchitis, increasing age)

\section{Step 4 Optimize bronchodilation with LABA + LAMA}

- Once ICS is completely withdrawn (i.e., at last step-down from lowest dose of ICS available), consider optimizing bronchodilation with LABA + LAMA (i.e., fixed-dose combination, if coverage is available, or separate devices) if not already done so in Step 3

- Choose a device that the patient is able to use effectively

\section{Step 5 Follow-up}

- See patient every 3 months in the first year, followed by an annual review, if COPD is stable and exacerbation-free 
patients with this level of eosinophilia were included in WISDOM. Results from these clinical trials were replicated in the 2-year real-life Outpatient Care with Long-Acting Bronchodilators: COPD Registry in Germany (DACCORD) study of approximately 6000 patients. ${ }^{79}$ In a subgroup analysis of that study, ICS withdrawal did not increase the risk of exacerbation. ${ }^{79}$

Although accumulating results suggest that ICS withdrawal may not negatively impact patients, results of other studies suggest otherwise. In a posthoc analysis of the TIOSPIR study of more than 17,000 patients, ICS therapy was associated with increased risk of exacerbation irrespective of exacerbation history. ${ }^{80}$ In a 5 -year follow-up of the GLUCOLD study, withdrawal of ICS in patients with moderate-to-severe COPD led to an increase in airway inflammation and a decrease in lung function. ${ }^{81}$ Further, while results of a meta-analysis of randomized trials and real-world studies showed that ICS withdrawal did not increase the rate of overall COPD exacerbation, ${ }^{82}$ the risk of moderate or severe exacerbation was increased versus continuing ICS-based therapy. Though the increased risk was not significantly different, it was clinically relevant. And, although significant impairment in lung function and QoL was observed with ICS withdrawal, the differences were smaller than the respective minimal clinically important difference. According to GOLD 2020, if patients were inappropriately prescribed ICS, do not respond to ICS treatment, or show side effects, a switch from LABA + ICS or $\mathrm{LABA}+\mathrm{LAMA}+\mathrm{ICS}$ to LABA + LAMA can be considered. ${ }^{7}$ Overall, these results emphasize that while ICS can be withdrawn to reduce unnecessary therapy and the risk of pneumonia in certain patients, careful monitoring is essential since withdrawal of ICS can decrease lung function or increase exacerbation risk in some patients. A stepby-step guide for ICS withdrawal has been proposed based on these observations (Figure 4). ${ }^{4,83}$

\section{Conclusion}

ICS is prescribed in many patients with COPD of varying severity and exacerbation risk. Overuse of ICS should be discouraged as long-term use is associated with various adverse events, primarily pneumonia. According to current GOLD treatment recommendations, ICS use should be considered in patients with more severe disease (group D patients with more symptoms), higher exacerbation risk ( $\geq 2$ moderate exacerbations or $\geq 1$ leading to hospitalization), history of asthma, or ACO. Identification of patients likely to benefit from ICS is essential as the potential risk of ICS therapy may outweigh the benefits if not correctly targeted. Step-by-step withdrawal of ICS should be completed in patients who are not clearly indicated for ICS therapy.

The author meets the criteria for authorship as recommended by the International Committee of Medical Journal Editors. The author received no direct compensation related to the development of the manuscript. Writing, editorial support, and formatting assistance was provided by Suchita Nath-Sain, PhD, and Maribeth Bogush, $\mathrm{PhD}$, of Cactus Communications, which was contracted and compensated by Boehringer Ingelheim Pharmaceuticals, Inc. (BIPI) for these services. BIPI was given the opportunity to review the manuscript for medical and scientific accuracy as well as intellectual property considerations.

To see this article online, please go to: http://jabfm.org/content/ 33/2/289.full.

\section{References}

1. Global initiative for asthma (GINA). Global strategy for asthma management and prevention, 2019. Available at https://ginasthma.org/gina-reports/. Accessed September 12, 2019.

2. Ejiofor S, Turner AM. Pharmacotherapies for COPD. Clin Med Insights Circ Respir Pulm Med 2013;7:17-34.

3. Barnes PJ. Inhaled corticosteroids in COPD: a controversy. Respiration 2010;80:89-95.

4. Kaplan AG. Applying the wisdom of stepping down inhaled corticosteroids in patients with COPD: a proposed algorithm for clinical practice. Int $\mathrm{J}$ Chron Obstruct Pulmon Dis 2015;10:2535-48.

5. Barnes PJ. Immunology of asthma and chronic obstructive pulmonary disease. Nat Rev Immunol 2008;8:183-92.

6. Chalmers JD, Poole C, Webster S, Tebboth A, Dickinson S, Gayle A. Assessing the healthcare resource use associated with inappropriate prescribing of inhaled corticosteroids for people with chronic obstructive pulmonary disease (COPD) in GOLD groups A or B: an observational study using the Clinical Practice Research Datalink (CPRD). Respir Res 2018;19:63.

7. Price D, West D, Brusselle G, et al. Management of COPD in the UK primary-care setting: an analysis of real-life prescribing patterns. Int J Chron Obstruct Pulmon Dis 2014;9:889-904.

8. Price D, Miravitlles M, Pavord I, et al. First maintenance therapy for COPD in the UK between 2009 and 2012: a retrospective database analysis. NPJ Prim Care Respir Med 2016;26:16061.

9. Petite SE. Characterization of chronic obstructive pulmonary disease prescribing patterns in the United States. Pulm Pharmacol Ther 2018;49:119-22. 
10. Global Strategy for the Diagnosis, Management, and Prevention of COPD, Global Initiative for Chronic Obstructive Lung Disease (GOLD). 2020. Available at https://goldcopd.org/. Accessed February 4, 2020.

11. Kew KM, Seniukovich A. Inhaled steroids and risk of pneumonia for chronic obstructive pulmonary disease. Cochrane Database Syst Rev 2014;CD010115.

12. Carlin BW, Schuldheisz SK, Noth I, Criner GJ. Individualizing the selection of long-acting bronchodilator therapy for patients with COPD: considerations in primary care. Postgrad Med 2017;129:725-33.

13. Yang IA, Clarke MS, Sim EH, Fong KM. Inhaled corticosteroids for stable chronic obstructive pulmonary disease. Cochrane Database Syst Rev 2012;CD002991.

14. Nannini LJ, Poole P, Milan SJ, Kesterton A. Combined corticosteroid and long-acting beta(2)-agonist in one inhaler versus inhaled corticosteroids alone for chronic obstructive pulmonary disease. Cochrane Database Syst Rev 2013;CD006826.

15. Kaplan A. Update: what is new in COPD in 2018? Can Geriatrics Soc 2018;7:2. Available at http:// canadiangeriatrics.ca/2018/01/update-what-is-newin-copd-in-2018/. Accessed May 17, 2019.

16. Bateman ED, Ferguson GT, Barnes N, et al. Dual bronchodilation with QVA149 versus single bronchodilator therapy: the SHINE study. Eur Respir J 2013;42:1484-94.

17. Wurst KE, St Laurent S, Hinds D, Davis KJ. Disease burden of patients with asthma/COPD overlap in a US claims database: impact of ICD-9 coding-based definitions. COPD 2017;14:200-9.

18. Divo M, Cote C, de Torres JP, et al. Comorbidities and risk of mortality in patients with chronic obstructive pulmonary disease. Am J Respir Crit Care Med 2012;186:155-61.

19. Bourbeau J, Bhutani M, Hernandez P, et al. CTS position statement: pharmacotherapy in patients with COPD_An update. Can J Resp Crit Care Sleep Med 2017;1:222-41.

20. Suissa S, Barnes PJ. Inhaled corticosteroids in COPD: the case against. Eur Respir J 2009;34:13-6.

21. Alsaeedi A, Sin DD, McAlister FA. The effects of inhaled corticosteroids in chronic obstructive pulmonary disease: a systematic review of randomized placebo-controlled trials. Am J Med 2002;113:59-65.

22. Ernst P, Saad N, Suissa S. Inhaled corticosteroids in COPD: the clinical evidence. Eur Respir J 2015;45: 525-37.

23. Spencer S, Evans DJ, Karner C, Cates CJ. Inhaled corticosteroids versus long-acting beta(2)-agonists for chronic obstructive pulmonary disease. Cochrane Database Syst Rev 2012;CD007033.

24. Nannini LJ, Lasserson TJ, Poole P. Combined corticosteroid and long-acting beta(2)-agonist in one inhaler versus long-acting beta(2)-agonists for chronic obstructive pulmonary disease. Cochrane Database Syst Rev 2012;CD006829.
25. Vogelmeier CF, Bateman ED, Pallante J, et al. Efficacy and safety of once-daily QVA149 compared with twice-daily salmeterol-fluticasone in patients with chronic obstructive pulmonary disease (ILLUMINATE): a randomised, double-blind, parallel group study. Lancet Respir Med 2013;1:51-60.

26. Zhong N, Wang C, Zhou X, et al. LANTERN: a randomized study of QVA149 versus salmeterol/ fluticasone combination in patients with COPD. Int J Chron Obstruct Pulmon Dis 2015;10:1015-26.

27. Roche N, Chapman KR, Claus F, et al. Blood eosinophils and response to maintenance chronic obstructive pulmonary disease treatment. Data from the FLAME trial. Am J Respir Crit Care Med 2017;195:1189-97.

28. Vogelmeier CF, Chapman KR, Miravitlles M, et al. Exacerbation heterogeneity in COPD: subgroup analyses from the FLAME study. Int J Chron Obstruct Pulmon Dis 2018;13:1125-34.

29. Wedzicha JA, Banerji D, Chapman KR, et al. Indacaterol-glycopyrronium versus salmeterol-fluticasone for COPD. N Engl J Med 2016;374:2222-34.

30. Vestbo J, Vogelmeier C, Small M, Higgins V. Understanding the GOLD 2011 strategy as applied to a real-world COPD population. Respir Med 2014;108:729-36.

31. Nishi SPE, Maslonka M, Zhang W, Kuo YF, Sharma G. Pattern and adherence to maintenance medication use in medicare beneficiaries with chronic obstructive pulmonary disease: 2008-2013. Chronic Obstr Pulm Dis 2018;5:16-26.

32. Crim C, Dransfield MT, Bourbeau J, et al. Pneumonia risk with inhaled fluticasone furoate and vilanterol compared with vilanterol alone in patients with COPD. Ann Am Thorac Soc 2015;12:27-34.

33. Lee MC, Lee CH, Chien SC, et al. Inhaled corticosteroids increase the risk of pneumonia in patients with chronic obstructive pulmonary disease: a Nationwide Cohort Study. Medicine 2015;94:e1723.

34. Yawn BP, Suissa S, Rossi A. Appropriate use of inhaled corticosteroids in COPD: the candidates for safe withdrawal. NPJ Prim Care Respir Med 2016;26:16068.

35. Pavord ID, Lettis S, Anzueto A, Barnes N. Blood eosinophil count and pneumonia risk in patients with chronic obstructive pulmonary disease: a patient-level meta-analysis. Lancet Respir Med 2016;4:731-41.

36. Suissa S, Coulombe J, Ernst P. Discontinuation of inhaled corticosteroids in COPD and the risk reduction of pneumonia. Chest 2015;148:1177-83.

37. Crim C, Calverley PMA, Anderson JA, et al. Pneumonia risk with inhaled fluticasone furoate and vilanterol in COPD patients with moderate airflow limitation: the SUMMIT trial. Respir Med 2017;131:27-34.

38. Vestbo J, Anderson JA, Brook RD, et al. Fluticasone furoate and vilanterol and survival in chronic obstructive pulmonary disease with heightened cardiovascular 
risk (SUMMIT): a double-blind randomised controlled trial. Lancet 2016;387:1817-26.

39. Gonzalez AV, Coulombe J, Ernst P, Suissa S. Long-term use of inhaled corticosteroids in COPD and the risk of fracture. Chest 2018;153:321-8.

40. Price DB, Russell R, Mares R, et al. Metabolic effects associated with ICS in patients with COPD and comorbid type 2 diabetes: a historical matched cohort study. PloS One 2016;11:e0162903.

41. Sannarangappa V, Jalleh R. Inhaled corticosteroids and secondary adrenal insufficiency. Open Respir Med J 2014;8:93-100.

42. Brode SK, Campitelli MA, Kwong JC, et al. The risk of mycobacterial infections associated with inhaled corticosteroid use. Eur Respir J 2017;50:1700037.

43. Beeh KM, Derom E, Echave-Sustaeta J, et al. The lung function profile of once-daily tiotropium and olodaterol via Respimat ${ }^{\circledR}$ is superior to that of twice-daily salmeterol and fluticasone propionate via Accuhaler ${ }^{\circledR}$ (ENERGITO ${ }^{\circledast}$ study). Int J Chron Obstruct Pulmon Dis 2016;11:193-205.

44. Donohue J, Worsley S, Zhu C, Hardaker L, Church A. Improvements in lung function with umeclidinium/ vilanterol versus fluticasone propionate/salmeterol in patients with moderate-to-severe COPD and infrequent exacerbations. Respir Med 2015;109:870-81.

45. Hoshino M, Ohtawa J, Akitsu K. Comparison of airway dimensions with once daily tiotropium plus indacaterol versus twice daily Advair ${ }^{\circledR}$ in chronic obstructive pulmonary disease. Pulm Pharmacol Ther 2015;30:128-33.

46. Magnussen H, Paggiaro P, Schmidt H, Kesten S, Metzdorf N, Maltais F. Effect of combination treatment on lung volumes and exercise endurance time in COPD. Respir Med 2012;106:1413-20.

47. Singh D, Worsley S, Zhu CQ, Hardaker L, Church A. Umeclidinium/vilanterol versus fluticasone propionate/salmeterol in COPD: a randomised trial. BMC Pulm Med 2015;15:91.

48. Vogelmeier C, Paggiaro PL, Dorca J, et al. Efficacy and safety of aclidinium/formoterol versus salmeterol/fluticasone: a phase 3 COPD study. Eur Respir J 2016;48:1030-9.

49. Goto A, Shibata Y, Ota E, et al. Long-acting muscarinic antagonist (LAMA) plus long-acting betaagonist (LABA) versus LABA plus inhaled corticosteroid (ICS) for stable chronic obstructive pulmonary disease (COPD). Cochrane Database Syst Rev 2017;2:CD012066.

50. Frith PA, Ashmawi S, Krishnamurthy S, et al. Efficacy and safety of the direct switch to indacaterol/ glycopyrronium from salmeterol/fluticasone in non-frequently exacerbating COPD patients: the FLASH randomized controlled trial. Respirology 2018;23:1152-9.

51. Lipson DA, Barnhart F, Brealey N, et al. Once-daily single-inhaler triple versus dual therapy in patients with COPD. N Engl J Med 2018;378:1671-80.
52. Suissa S, Drazen JM. Making sense of triple inhaled therapy for COPD. N Engl J Med 2018;378:1723-4.

53. Ishiura Y, Fujimura M, Shiba Y, Ohkura N, Hara J, Kasahara K. A comparison of the efficacy of once-daily fluticasone furoate/vilanterole with twice-daily fluticasone propionate/salmeterol in asthma-COPD overlap syndrome. Pulm Pharmacol Ther 2015;35:28-33.

54. Lee SY, Park HY, Kim EK, et al. Combination therapy of inhaled steroids and long-acting beta2agonists in asthma-COPD overlap syndrome. Int $\mathrm{J}$ Chron Obstruct Pulmon Dis 2016;11:2797-803.

55. Siva R, Green RH, Brightling CE, et al. Eosinophilic airway inflammation and exacerbations of COPD: a randomised controlled trial. Eur Respir J 2007;29:906-13.

56. Pascoe S, Locantore N, Dransfield MT, Barnes NC, Pavord ID. Blood eosinophil counts, exacerbations, and response to the addition of inhaled fluticasone furoate to vilanterol in patients with chronic obstructive pulmonary disease: a secondary analysis of data from two parallel randomised controlled trials. Lancet Respir Med 2015;3:435-42.

57. Siddiqui SH, Guasconi A, Vestbo J, et al. Blood eosinophils: a biomarker of response to extrafine beclomethasone/formoterol in chronic obstructive pulmonary disease. Am J Respir Crit Care Med 2015;192:523-5.

58. Zysman M, Deslee G, Caillaud D, et al. Relationship between blood eosinophils, clinical characteristics, and mortality in patients with COPD. Int J Chron Obstruct Pulmon Dis 2017;12:1819-24.

59. Casanova C, Celli BR, de-Torres JP, et al. Prevalence of persistent blood eosinophilia: relation to outcomes in patients with COPD. Eur Respir J 2017;50:1701162.

60. Bafadhel M, McKenna S, Terry S, et al. Blood eosinophils to direct corticosteroid treatment of exacerbations of chronic obstructive pulmonary disease: a randomized placebo-controlled trial. Am J Respir Crit Care Med 2012;186:48-55.

61. Turato G, Semenzato U, Bazzan E, et al. Blood eosinophilia neither reflects tissue eosinophils nor worsens clinical outcomes in chronic obstructive pulmonary disease. Am J Respir Crit Care Med 2018;197:1216-9.

62. Harlander $M$, Barrecheguren $M$, Turel $M$, Miravitlles M. Should patients switched from D to B in the GOLD 2017 classification be discontinued from inhaled corticosteroids? COPD 2017;14:465-8.

63. Tsiligianni I, Kaplan AG. Are blood eosinophils a prime-time biomarker for COPD management decisions? Int J Chron Obstruct Pulmon Dis 2018;13:1889-91.

64. Frith PA, Thompson PJ, Ratnavadivel R, et al. Glycopyrronium once-daily significantly improves lung function and health status when combined with salmeterol/fluticasone in patients with COPD: the GLISTEN study, a randomised controlled trial. Thorax 2015;70:519-27. 
65. Lipson DA, Barnacle H, Birk R, et al. FULFIL trial: once-daily triple therapy for patients with chronic obstructive pulmonary disease. Am J Respir Crit Care Med 2017;196:438-46.

66. Siler TM, Kerwin E, Sousa AR, Donald A, Ali R, Church A. Efficacy and safety of umeclidinium added to fluticasone furoate/vilanterol in chronic obstructive pulmonary disease: results of two randomized studies. Respir Med 2015;109:1155-63.

67. Singh D, Papi A, Corradi M, et al. Single inhaler triple therapy versus inhaled corticosteroid plus long-acting beta2-agonist therapy for chronic obstructive pulmonary disease (TRILOGY): a doubleblind, parallel group, randomised controlled trial. Lancet 2016;388:963-73.

68. Sousa AR, Riley JH, Church A, Zhu CQ, Punekar $Y$, Fahy $W$. The effect of umeclidinium added to inhaled corticosteroid/long-acting beta2-agonist in patients with symptomatic COPD: a randomised, double-blind, parallel-group study. NPJ Prim Care Respir Med 2016;26:16031.

69. Singh D, Corradi M, Spinola M, et al. Triple therapy in COPD: new evidence with the extrafine fixed combination of beclomethasone dipropionate, formoterol fumarate, and glycopyrronium bromide. Int J Chron Obstruct Pulmon Dis 2017;12:2917-28.

70. Vestbo J, Papi A, Corradi M, et al. Single inhaler extrafine triple therapy versus long-acting muscarinic antagonist therapy for chronic obstructive pulmonary disease (TRINITY): a double-blind, parallel group, randomised controlled trial. Lancet 2017;389:1919-29.

71. Papi A, Vestbo J, Fabbri L, et al. Extrafine inhaled triple therapy versus dual bronchodilator therapy in chronic obstructive pulmonary disease (TRIBUTE): a double-blind, parallel group, randomised controlled trial. Lancet 2018;391:1076-84.

72. Ferguson GT, Rabe KF, Martinez FJ, et al. Triple therapy with budesonide/glycopyrrolate/formoterol fumarate with co-suspension delivery technology versus dual therapies in chronic obstructive pulmonary disease (KRONOS): a double-blind, parallelgroup, multicentre, phase 3 randomised controlled trial. Lancet Respir Med 2018;6:747-58.

73. Rossi A, Molen T, Olmo R, et al. INSTEAD: a randomised switch trial of indacaterol versus salmeterol/fluticasone in moderate COPD. Eur Respir J 2014;44:1548-56.

74. Rossi A, Guerriero M, Corrado A. Withdrawal of inhaled corticosteroids can be safe in COPD patients at low risk of exacerbation: a real-life study on the appropriateness of treatment in moderate COPD patients (OPTIMO). Respir Res 2014;15:77.

75. Magnussen H, Diss B, Rodriguez-Roisin R, et al. Withdrawal of inhaled glucocorticoids and exacerbations of COPD. N Engl J Med 2014;371: 1285-94.
76. Calverley PM, Tetzlaff K, Vogelmeier C, et al. Eosinophilia, frequent exacerbations, and steroid response in chronic obstructive pulmonary disease. Am J Respir Crit Care Med 2017;196:1219-21.

77. Watz H, Tetzlaff K, Wouters EFM, et al. Blood eosinophil count and exacerbations in severe chronic obstructive pulmonary disease after withdrawal of inhaled corticosteroids: a post-hoc analysis of the WISDOM trial. Lancet Respir Med 2016;4:390-8.

78. Chapman KR, Hurst JR, Frent SM, et al. Longterm triple therapy de-escalation to indacaterol/glycopyrronium in COPD patients (SUNSET): a randomized, double-blind, triple-dummy clinical trial. Am J Respir Crit Care Med 2018;198:329-39.

79. Vogelmeier C, Worth H, Buhl R, Criée CP, et al. "Real-life" inhaled corticosteroid withdrawal in COPD: a subgroup analysis of DACCORD. Int $\mathrm{J}$ Chron Obstruct Pulmon Dis 2017;12:487-94.

80. Calverley PM, Tetzlaff K, Dusser D, et al. Determinants of exacerbation risk in patients with COPD in the TIOSPIR study. Int J Chron Obstruct Pulmon Dis 2017;12:3391-405.

81. Kunz LI, Hacken NHT, Lapperre TS, et al. Airway inflammation in COPD after long-term withdrawal of inhaled corticosteroids. Eur Respir J 2017;49.

82. Calzetta L, Matera MG, Braido F, et al. Withdrawal of inhaled corticosteroids in COPD: a meta-analysis. Pulm Pharmacol Ther 2017;45:148-58.

83. Kaplan AG, Román-Rodríguez M, Price DB, Tsiligianni I. Appropriate use and withdrawal of inhaled corticosteroids in patients with COPD. IPCRG desktop helper no 6. March 2017. Available at https://www.theipcrg.org/download/attachments/ 35390454/Summary\%20of\%20Evidence\%20v.2.pdf? version $=1 \&$ modificationDate $=1532348072000 \&$ api $=$ v2. Accessed May 17, 2018.

84. Lim HS, Choi SM, Lee J, et al. Responsiveness to inhaled corticosteroid treatment in patients with asthma-chronic obstructive pulmonary disease overlap syndrome. Ann Allergy Asthma Immunol 2014;113:652-7.

85. Chapman KR, Hurst J, Frent S, et al. Withdrawal of inhaled corticosteroids from COPD patients inhaling long-term triple therapy: the SUNSET Study. Am J Respir Crit Care Med 2018;197:A1009.

86. Halpin DMG, Birk R, Brealey N, et al. Single-inhaler triple therapy in symptomatic COPD patients: FULFIL subgroup analyses. ERJ Open Res 2018;4.

87. Papi A, Kostikas K, Wedzicha JA, et al. Dual bronchodilation response by exacerbation history and eosinophilia in the FLAME study. Am J Respir Crit Care Med 2018;197:1223-6.

88. Anzueto AR, Kostikas K, Mezzi K, et al. Indacaterol/glycopyrronium versus salmeterol/fluticasone in the prevention of clinically important deterioration in COPD: results from the FLAME study. Respir Res 2018;19:121. 